\title{
Protease Production from UV Mutated Bacillus subtilis
}

\author{
M. G. Sher*, M. Nadeem, Q. Syed, M. Irfan and S. Baig \\ Food and Biotechnology Research Centre, PCSIR Labs, Complex, Lahore-54600, Pakistan
}

\begin{abstract}
UV mutation of the strain has significant contributation to enhance the yield of protease enzyme from Bacillus subtilis bacteria under the cultivation conditions in submerged fermentation. The fermentation medium used for the production of protease composed of carbon sources $1 \%$, organic $1 \%$ or inorganic nitrogen sources $0.5 \%, \mathrm{~K}_{2} \mathrm{HPO}_{4} 0.2 \%, \mathrm{CaCl}_{2} 0.04 \%$ and $\mathrm{MgSO}_{4} 0.02 \%$ by mutated Bacillus subtilis G-4 under the optimum parameters which are important to induce the mutated strain to produce high units of the protease, which were temperature $37.5{ }^{\circ} \mathrm{C}, \mathrm{pH} 9$, inoculum size $3 \% \mathrm{v} / \mathrm{v}$, glucose $1 \%$ as carbon source and peptone $1 \%$ as nitrogen source were give the maximum $455.25 \pm 1.66$ units of protease. The results of stability studies revealed that protease of $B$. subtilis $\mathrm{G}-4$ was stable over a broad range of temperature (30 to $60^{\circ} \mathrm{C}$ ) and $\mathrm{pH}(8$ to 12$)$. However, maximum activity $(155.45 \mathrm{U} / \mathrm{ml})$ was observed at temperature $50^{\circ} \mathrm{C}$ and $\mathrm{pH} 10$. These characteristics render its potential use in detergent industries for detergent formulation.
\end{abstract}

Key words : Protease, UV mutation, B. subtilis, Parameters

\section{Introduction}

Proteases are one of the industrially most important enzymes. Proteases constitute a large and complex group of enzyme which differ in properties such as specificity, active site and catalytic mechanism, $\mathrm{pH}$, temperature optima and stability profile (Sandya et al., 2004). Proteases are wide spread in nature such as plants, animals and microorganisms (Rao et al., 1998). Microbial proteases can be produced from bacteria, fungi and yeast through submerged and solidstate fermentation (Kumar and Takagi, 1999, (Anwar and Saleemuddin, 2001) and (Haki and Rakshits, 2003). The success of microbial proteases in food and other biotechnological systems could be attributed to the broad biochemical diversity of the microorganisms, to the genetic manipulation of the organisms and the improvement of the techniques in the enzyme production, purification and characterization. Alkaline proteases have wide use in industrial processes such as food, leather, pharmaceutical and detergent formulation and for cleaning of membranes used in protein ultra filtration (Kumar and Takagi, 1999) and (Dayanandan et al., 2003). Protease is one of the most important industrial enzymes occupying nearly $60 \%$ of the enzyme sales (Beg et al., 2003; Adinarayan et al., 2003). It is produced mainly by many members belonging to genus Bacilli especially, $B$. licheniformis; B. horikoshii, B. sphaericus (Mehrotra et al., 1999).

Now a days, detergent industries are mainly focused on alkaline protease for its use in all types of laundry detergents and in automatic dishwashing detergents to degrade proteinaceous stains (Maurer, 2004). The cost of the enzyme is a major issue in enzyme production and their applications in various industrial processes. Therefore utilization of cheap industrial waste has significant impact on enzyme utilization. The present study was conducted to improve bacterial strain through mutation and optimized the conditions such as $\mathrm{pH}$, temperature, size of inoculum and growth medium to enhance enzyme yield to make the process of production cost effective.

\section{Materials and Methods}

\section{Microorganism}

The parent Bacillus subtilis was obtained from Microbiology Lab, Food and Biotechnology Research Centre, PCSIR Labs Complex Lahore. The Bacillus subtilis was grown on nutrient agar slant (Oxoid) for $24 \mathrm{hr}$ at $37^{\circ} \mathrm{C}$. The culture was then preserved at $4^{\circ} \mathrm{C}$ and shifting to new slants after 25 days in order to keep viable. The $\mathrm{pH}$ of the medium was adjusted at 9 with $1 \mathrm{~N} \mathrm{HCl} / \mathrm{NaOH}$.

\section{Bacterial suspension}

For suspesion preparation, $10 \mathrm{~mL}$ of sterile distilled water was added in 24 hour old Bacillus subtilis slant and cells were scraped with inoculating loop in Laminar Air Hood,

\footnotetext{
*Corresponding author. E-mail: muhammadgulsher@yahoo.com,gulpk25@yahoo.com
} 
(LABNICO). This bacterial suspension was used for UV treatment. The same procedure was used for inoculum preparation of mutated strain and bacterial suspension was used $108^{-10} \mathrm{cfu} / \mathrm{mL}$.

\section{Mutagenesis by ultraviolet irradiation}

In six test tubes with the aforesaid bacterial suspension were taken and one of them (the control) was kept aside in dark and the rest five were given UV radiation (2600 AO) for time periods varying from 5 minutes to 25 minutes. A $0.1 \mathrm{~mL}$ of the UV treated bacterial suspensions was then inoculated in $20 \mathrm{~mL}$ Petri plates containing nutrient agar. These were incubated for $48 \mathrm{hr}$ at $37^{\circ} \mathrm{C}$ for colony formation and colonies were counted under colony counter. The screening of the mutant was performed in $20 \mathrm{ml}$ of Petri plates $1 \%$ skim milk and $2 \%$ agar. After the incubation of $48 \mathrm{hr}$ at $37^{\circ} \mathrm{C}$, the plates were flooded with TCA solution for 5 minutes and the transparent circular zones around the colonies in an opaque white background detected protease secretion. Mutants for hyper-production of protease were detected visually by the intensity of the zones.

\section{Fermentation of growth medium}

The medium used for the production of protease was composed of carbon sources $1 \%$, organic $1 \%$ or inorganic nitrogen sources $0.5 \%, \mathrm{~K}_{2} \mathrm{HPO}_{4} 0.2 \%, \mathrm{CaCl}_{2} 0.04 \%$ and $\mathrm{MgSO}_{4}$ $0.02 \%$. The $\mathrm{pH} 9$ of the medium was adjusted with $1 \mathrm{~N} \mathrm{HCl}$ $/ \mathrm{NaOH}$ before sterilization at $121^{\circ} \mathrm{C}$ for $15 \mathrm{~min}$. Three percent $(\mathrm{v} / \mathrm{v})$ of $24 \mathrm{~h}$ old inoculum suspension was transferred to $50 \mathrm{~mL}$ of growth medium in $250 \mathrm{ml}$ Erlenmeyer flask. The inoculated fermentation medium was incubated in water bath shaker (Eyla, Japan) at $150 \mathrm{rpm}$ at $37.5^{\circ} \mathrm{C}$ for the $48 \mathrm{hr}$. After that fermentated broth was centrifuged at $4{ }^{\circ} \mathrm{C}$ for 10 minutes at $10,000 \mathrm{rpm}$ to get the clear solution.

\section{Parameters}

Various process parameters such as effect of inoculum size ( 1 to $6 \%$ ), various temperatures ranges $\left(25\right.$ to $\left.45^{\circ} \mathrm{C}\right)$ and different initial $\mathrm{pH}$ (6 to 12) were studied to optimize the level of each parameter for maximum protease production by Bacillus subtilis G-4.

\section{Effect of Nitrogen Sources}

The importance of the nitrogen for the microorganism is very crucial and the various sources organic nitrogen such as corn steep liquor, peptone, urea and yeast extract at rate of
$1 \%$, where as inorganic nitrogen sources like $\mathrm{NaNO}_{3}$, $\mathrm{NH}_{4} \mathrm{H}_{2} \mathrm{PO}_{4}, \mathrm{NH}_{4} \mathrm{Cl},\left(\mathrm{NH}_{4}\right)_{2} \mathrm{HPO}_{4}, \mathrm{NH}_{4} \mathrm{NO}_{3}$, and $\left(\mathrm{NH}_{4}\right)_{2} \mathrm{SO}_{4}$ were added at rate of $0.5 \%$ in medium for the synthesis of enzyme by Bacillus subtilis G-4.

\section{Effect of Carbon Sources}

The various carbon sources have different effect on the enzyme production by different microorganism and evaluated the effect of each carbon sources such as glucose, sucrose; fructose, maltose, xylose, sorbitol and galactose at rate of $1 \%$ in medium used for protease production.

\section{Protease activity}

Protease activity was determined by a method of (Yang and Huang, 1994). The reaction mixture containing $2 \mathrm{~mL}$ of $1 \%$ casein solution in $0.05 \mathrm{M}$ glycine- $\mathrm{NaOH}$ buffer $(\mathrm{pH}=11)$ and $1 \mathrm{~mL}$ of enzyme solution were incubated at $60{ }^{\circ} \mathrm{C}$ for $15 \mathrm{~min}$ and the reaction was then stopped with the addition of $3 \mathrm{~mL}$ of $10 \%$ trichloroacetic acid. After $10 \mathrm{~min}$ the entire mixture was centrifuged at 9000rpm for $10 \mathrm{~min}$ at $4{ }^{\circ} \mathrm{C}$ and absorbance of the liberated tyrosine was measured with respect to the blank at $280 \mathrm{~nm}$. One proteolytic unit (U) was defined as the amount of the enzyme that releases $1 \mu \mathrm{g}$ of tyrosine per min under assay conditions.

\section{Stability study}

Stability studied of alkaline protease in the presence and absences of metal ions were conducted to find enzyme commercial exploitation.

\section{Effect of Metal ions on the thermo stability}

The thermostabilty of protease was studied by incubating the enzyme in water bath (Eyla, Japan) at different temperature ranges 30 to $70^{\circ} \mathrm{C}$ for $1 \mathrm{~h}$ in the absence or presence of $\mathrm{Ca}^{2+}, \mathrm{Cu}^{2+}$ and $\mathrm{Mg}^{2+}$ ions at concentration of $5 \mathrm{mM}$. After the treatment the enzyme activity was measured according to the standard assay.

\section{Effect of Metal ions on the pH stability and activity of Enzyme}

The $\mathrm{pH}$ stability of enzyme was observed at $\mathrm{pH} 7-14$ for 8 $\mathrm{h}$ at $40^{\circ} \mathrm{C}$ in the presence or absence of $\mathrm{Ca}^{2+}, \mathrm{Cu}^{2+}$ and $\mathrm{Mg}^{2+}$ at the concentration of $5 \mathrm{mM}$. Various $\mathrm{pH}$ value were adjusted with sodium phosphate buffer $(\mathrm{pH} \mathrm{6-7),} \mathrm{Tris-HCl}$ buffer (pH 8-9) and glycine $\mathrm{NaOH}$ buffer (pH 10-12). After the treatment the enzyme activity was measured according to the standard assay. 


\section{Result and Discussion}

\section{Improvement of Strain by mutation}

The successful development of the various strains required in the fermentation industry can be improved by mutation. The productivity of the parent strain Bacillus subtilis under investigation was improved by UV mutation. The survival data obtained on UV treatment for varying time periods are presented in Table I.

Table I: Survival rate for Bacillus subtilis on UV treatment

\begin{tabular}{l|c|c}
\hline $\begin{array}{l}\text { UV light Exposure } \\
\text { (minutes) }\end{array}$ & $\begin{array}{c}\text { Number of } \\
\text { colony appear }\end{array}$ & $\begin{array}{c}\text { Survival } \\
\text { rate }(\%)\end{array}$ \\
\hline 0 & 3000 & 100 \\
5 & 21 & 0.83 \\
10 & 12 & 0.4 \\
15 & 8 & 0.26 \\
20 & 4 & 0.13 \\
25 & 1 & 0.03 \\
\hline
\end{tabular}

Survival rate $(\%)$ was calculated as follows:

For a treatment time $(\mathrm{t})$ Survival $(\%)=100 \mathrm{x}$ (Colony count obtained for time $(\mathrm{t})) / 3000$

UV treatment for 10 minutes resulted in a strain designated as Bacillus subtilis. It was observed that morphologically both parent and mutant strains looked alike. On studying the enzyme production on fermentation medium containing rice polish, it was found that the mutant was active giving approximately about 2 fold increases in protease production over the parent strain (i.e. parent strain gave $235.23 \pm 1.86$ $\mathrm{U} / \mathrm{ml}$ whereas $455.25 \pm 1.76 \mathrm{U} / \mathrm{ml})$. It was reported that improvement of strain by UV exposure is very useful for the protease production (Gupta et al., 2002).

\section{Effect of Inoculum size}

It is generally necessary to optimized age and size of the inoculum, because low density gives insufficient biomass and high density produces too much biomass and resulting depleting of nutrients necessary for protease fermentation. Different inoculum sizes were used and 3\% inoculum of mutated Bacillus subtilis G-4 gave $(412.31 \pm 1.45 \mathrm{U} / \mathrm{ml})$ units of protease (Fig. 1). The researchers were reported that inoculum size has crucial effect in fermentation process through microognims (Mangat et al.,1998; Hornbeak et al., 2004) Safey et al., (2004) optimized the $24 \mathrm{hr}$ aged inoculum and size $1.0 \mathrm{cell} / \mathrm{mL}\left(7.0 \times 10^{3}\right)$ for the production of protease by Bacillus subtilis.

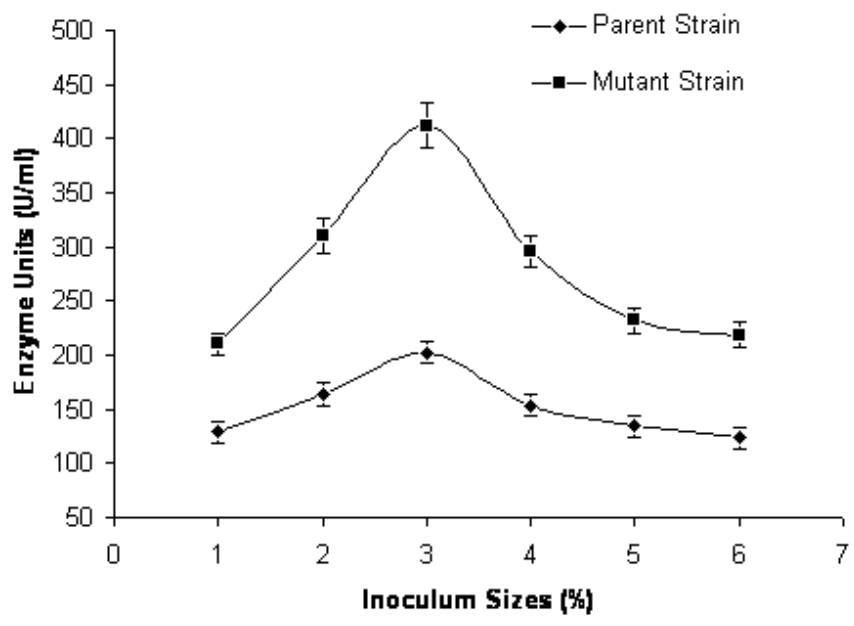

Fig. 1: Effect of different inoculum size on protease production by parent and mutagenized strains of Bacillus subtilis G-4 in submerged fermentation. Bars indicate the SD among triplicates

\section{Effect of Initial pH}

The metabolic activities of the microorganisms were very sensitive for $\mathrm{pH}$ variation. The maximum protease activity $(451.12 \pm 1.85 \mathrm{U} / \mathrm{ml})$ was found at $\mathrm{pH} 9$ by Bacillus subtilis $G-4$, however a further change in $\mathrm{pH}$ decreases the enzyme yield (Fig. 2). Similar finding was observed by (Ul-haq et al., (2006), that maximum protease is obtained at $\mathrm{pH} 9$ for B.subtilis IH-72 in a bioreactor. Ali et al., (1998) has prescribed that optimum $\mathrm{pH}$ have important role in enzyme yield. It was reported that microorganisms exhibit more than one $\mathrm{pH}$ optimum for growth depending on the growth conditions, particularly, metal ions and temperature (Arai et al., 2003).

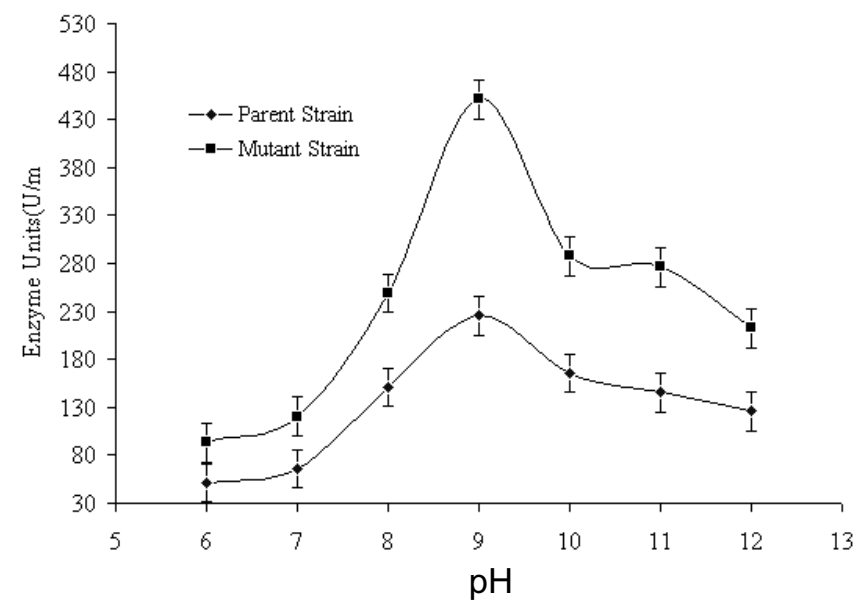

Fig. 2: Effect of various initial $\mathrm{pH}$ of the medium on protease production by parent and mutagenized strains of Bacillus subtilis G-4 in submerged fermentation. Bars indicate the SD among triplicates 


\section{Effect of Temperature}

The maximum protease units $442.43 \pm 1.75 \mathrm{U} / \mathrm{ml}$ were observed at $37.5^{\circ} \mathrm{C}$ (Fig. 3). The same finding was reported by (Banerjee et al., 1999), worked with Bacillus brevis in shake flask and found that protease enzyme show the maximum activity at $37^{\circ} \mathrm{C}$. The worker were observed that maximum proteinase production was observed at $37^{\circ} \mathrm{C}$, however, proteinase production was not affected by temperature within the range studied $\left(7-45^{\circ} \mathrm{C}\right)$. The researcher (Joo et al., 2003) was reported that $45^{\circ} \mathrm{C}$ is optimum temperature for protease production with the Bacillus horikoshii. The worker were investigated that production of proteases by Streptococcus suis serotype 2 was required optimum temperature ranged from 25 to $42^{\circ} \mathrm{C}$ (Wery et al. 2003; Jobin and Grenier, 2003).

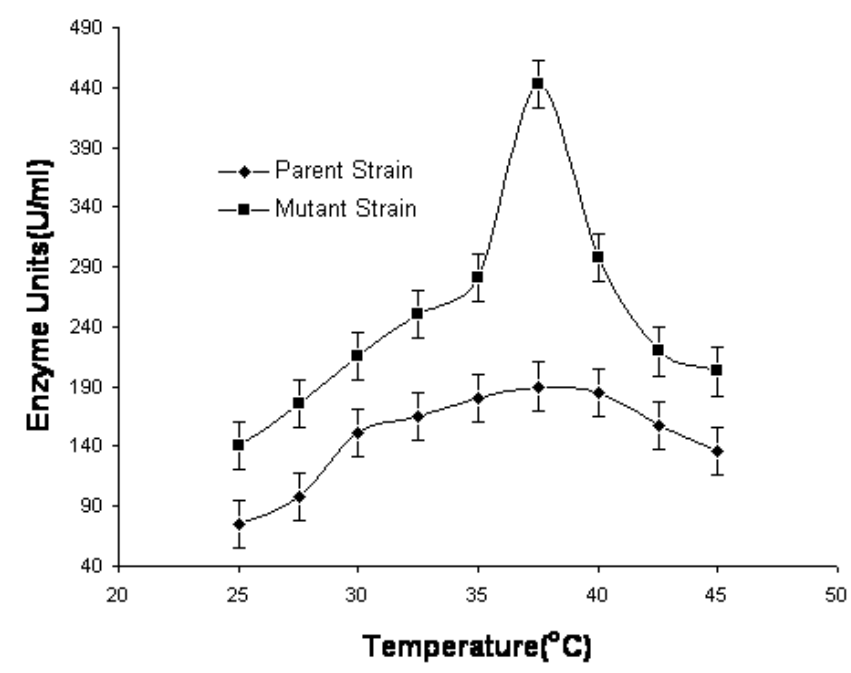

Fig. 3: Effect of different incubation temperatures on protease production by parent and mutagenized strains of Bacillus subtilis G-4 in submerged fermentation. Bars indicate the SD among triplicates

\section{Effect of Nitrogen Sources}

The macro and micronutrients are very important for the growth of microorganism. The importance of the nitrogen for the microorganism is very crucial. The various organic nitrogen sources such as corn steep liquor, peptone, urea and yeast extract were added at a rate of $1 \%$, where as inorganic nitrogen sources like $\mathrm{NaNO}_{3}, \mathrm{NH}_{4} \mathrm{H}_{2} \mathrm{PO}_{4}, \mathrm{NH}_{4} \mathrm{Cl}$, $\left(\mathrm{NH}_{4}\right)_{2} \mathrm{HPO}_{4}, \mathrm{NH}_{4} \mathrm{NO}_{3}$ and $\left(\mathrm{NH}_{4}\right)_{2} \mathrm{SO}_{4}$ were added at a rate of $0.5 \%$ in medium for the synthesis of enzyme. Among the organic nitrogen peptone, corn steep liquor and yeast extract were contributed to induce the protease but the peptone was best enhancer in this study (Table II). The inorganic nitrogen sources were less enhancer of protease as comparative to organic. The maximum protease units were observed in harvesting batch which was supplemented with $\left(\mathrm{NH}_{4}\right)_{2} \mathrm{SO}_{4}$. The researcher were reported that among various complex nitrogen sources, yeast extract and casamino acid were also found the most suitable sources for alkaline protease production in earlier investigations (Prakasham et al., 2006; Rahman et al., 2005). The worker was reported that organic nitrogen sources were better for enzyme production than inorganic ones (Feng et al., 2001). Nadeem et al., (2008) was reported that inorganic nitrogen sources, especially ammonium salts, inhibited the growth and protease production by $B$. licheniformis $\mathrm{N}-2$.

Table II: Effect of Various organic and inorganic nitrogen sources on the protease production by $B$. subtilis G-4 in submerged fermentation at $37.5^{\circ} \mathrm{C}$ for 48 hour with agitation $150 \mathrm{rpm}$.

\begin{tabular}{l|c|c}
\hline Organic nitrogen & \multicolumn{2}{|c}{ Enzyme production $(\mathrm{U} / \mathrm{mL})$} \\
\hline & Parent strain & Mutant strain \\
\hline Control & $155.34 \pm 1.12$ & $224.34 \pm 1.18$ \\
Corn steep Liquor & $185.56 \pm 1.21$ & $275.86 \pm 1.31$ \\
Peptone & $225.67 \pm 1.41$ & $425.97 \pm 1.51$ \\
Urea & $85.58 \pm 1.01$ & $155.48 \pm 1.01$ \\
Yeast extract & $125.69 \pm 1.14$ & $215.24 \pm 1.21$ \\
Beef extract & $105.47 \pm 1.21$ & $194.43 \pm 1.25$ \\
\hline Inorganic nitrogen & \multicolumn{2}{|c}{ Enzyme production (U/mL) } \\
\cline { 2 - 3 } & Parent strain & Mutant strain \\
\hline Control & $155.34 \pm 1.12$ & $224.34 \pm 1.18$ \\
$\mathrm{NaNO}_{3}$ & $125.46 \pm 1.01$ & $214.94 \pm 1.16$ \\
$\mathrm{NH}_{4} \mathrm{H}_{2} \mathrm{PO}_{4}$ & $95.57 \pm 1.12$ & $182.34 \pm 1.08$ \\
$\mathrm{NH}_{4} \mathrm{CL}$ & $125.58 \pm 1.21$ & $193.39 \pm 1.12$ \\
$\left(\mathrm{NH}_{4}\right)_{2} \mathrm{HPO}_{4}$ & $92.69 \pm 1.11$ & $169.74 \pm 1.15$ \\
$\mathrm{NH}_{4} \mathrm{NO}_{3}$ & $107.97 \pm 1.21$ & $202.34 \pm 1.28$ \\
$\left(\mathrm{NH}_{4}\right)_{2} \mathrm{SO}_{4}$ & $175.56 \pm 1.23$ & $278.38 \pm 1.36$ \\
\hline
\end{tabular}

Values are the average of three replicates. \pm denotes the standard deviation among triplicates.

\section{Effect of Carbon Sources}

The various carbon sources have different effect on the enzyme production by different microorganism. The effect 
of different carbon sources such as glucose, sucrose, fructose, maltose, xylose, sorbitol and galactose were studied at rate of $1 \%$ in medium and results were indicated that glucose was best protease enzyme enhancer in Bacillus subtlis G-4 (Table III). The similar findings were observed by many other worker that glucose has significant effect on protease production (Nadeem et al., 2008; He et al., 2003; Shafee et al., 2005). Some other researchers were also found a considerable increase in alkaline protease production by Bacillus $s p$. with glucose as a carbon source compared to control (without external carbon source) (Adinarayana et al., 2003; Prakasham et al., 2006).

Table III: Effect of Various Carbon sources on the protease production by $B$. subtilis $\mathrm{G}-4$ in submerged fermentation at $37.5^{\circ} \mathrm{C}$ for 48 hour with agitation $150 \mathrm{rpm}$.

\begin{tabular}{l|c|c}
\hline Carbon sources & \multicolumn{2}{|c}{ Enzyme production $(\mathrm{U} / \mathrm{mL})$} \\
\hline & Parent strain & Mutant strain \\
\hline Control & $145.42 \pm 1.18$ & $208.98 \pm 1.23$ \\
Glucose & $185.74 \pm 1.32$ & $324.24 \pm 1.38$ \\
Sucrose & $135.16 \pm 1.11$ & $234.74 \pm 1.26$ \\
Fructose & $85.57 \pm 1.02$ & $142.34 \pm 1.08$ \\
Maltose & $92.48 \pm 1.01$ & $153.34 \pm 1.12$ \\
Xlose & $93.69 \pm 1.15$ & $165.44 \pm 1.17$ \\
Sorbitol & $75.47 \pm 1.08$ & $143.64 \pm 1.12$ \\
Galactose & $78.56 \pm 1.03$ & $138.28 \pm 1.21$ \\
\hline
\end{tabular}

Values are the average of three replicates. \pm denotes the standard deviation among triplicates.

\section{Stability study}

\section{Effect of Metal ions the thermo stability}

The thermo stability of alkaline protease was examined by measuring the residual activity at $40{ }^{\circ} \mathrm{C}$ after incubation of the enzyme without substrate for various temperatures ranging from 30 to $70{ }^{\circ} \mathrm{C}$ in the presence of $\mathrm{Ca}^{2+}, \mathrm{Cu}^{2+}$ and $\mathrm{Mg}^{2+}$ ions and along with substrate for $30 \mathrm{~min}$ at $40{ }^{\circ} \mathrm{C}$ (Fig. 4). The enzyme was observed to be stable up to $50{ }^{\circ} \mathrm{C}$ and above this temperature its activity was decreased. The enzyme showed its $100 \%$ activity at $50{ }^{\circ} \mathrm{C}$ and $61 \%$ at $60{ }^{\circ} \mathrm{C}$ in the presence of metal ions. Johnvesly et al., (2002) has found that $70{ }^{\circ} \mathrm{C}$ was optimum temperature for protease activity which was produced from thermoalkaliphilic Bacillus $s p$. JB-99. Lee et al, (2002) has reported that, the optimum tem- perature of protease has ranged from 40 to $50{ }^{\circ} \mathrm{C}$. Other workers have observed that highest activity of extracellular alkaline protease produced from the alkalophilic bacterium Alcaligenes faecalis was exhibited at $55^{\circ} \mathrm{C}$ (Berla and Suseela, 2002). Ammar et al., (2003) has reported that, the optimum temperature for thermostable purified protease enzyme was $55^{\circ} \mathrm{C}$. In the finding of Nadeem (Nadeem et al., 2008 ) it was indicated that $5 \mathrm{mM} \mathrm{Ca}^{2+}$ increased the stability on alkaline protease.

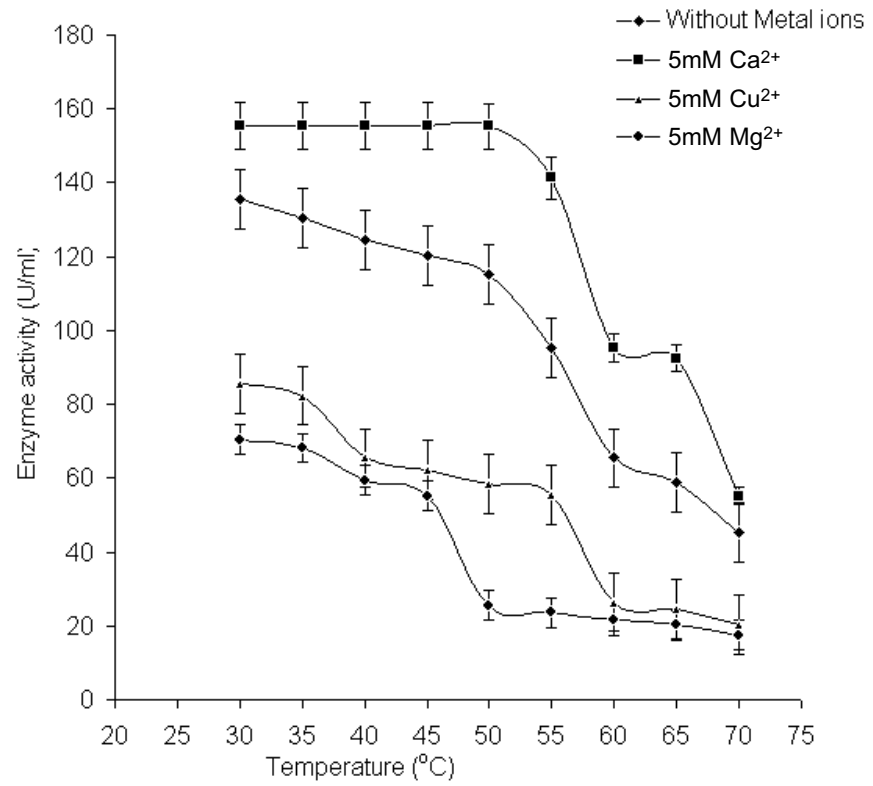

Fig. 4: Effect of different metal ions on the thermostability of protease produced by mutagenized strains of Bacillus subtilis G-4 in submerged fermentation. Bars indicate the SD among triplicates

\section{Effect of pH on the stability}

These results of $\mathrm{pH}$ stability studied showed that enzyme wss stable at $\mathrm{pH} 10$ and lost $50 \%$ of its residual activity at pH 11 (Fig. 5). The pH level is one of the factors that affect not only structure of enzymes but all proteins. The $\mathrm{pH}$ values beyond the range of 8-11 could alter the three-dimensional structure of alkaline protease by disturbing the electrostatic interactions among the charged amino acids, resulting in loss of enzyme activity. Similar results was reported by (Balassa et al., 2000), who found $60 \%$ proteolytic retention at $\mathrm{pH} 10$ in the presence of $5 \mathrm{mM} \mathrm{Ca}^{2+}$ ions. It was reported that the optimal $\mathrm{pH}$ for purified extracellular alkaline protease produced 


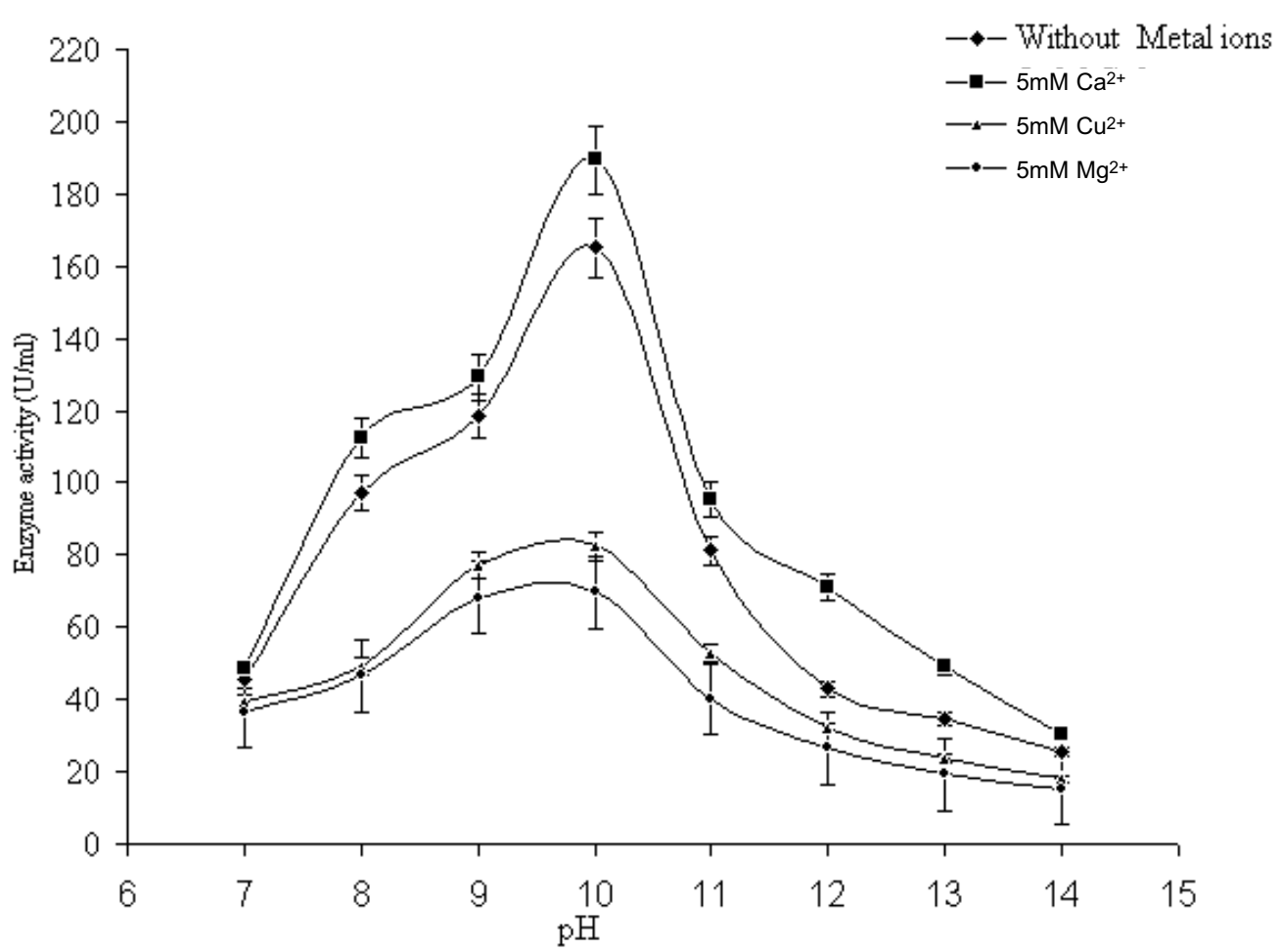

Fig . 5: Effect of different metal ions on the pH stability of protease produced by mutagenized strains of Bacillus subtilis G-4 in submerged fermentation. Bars indicate the SD among triplicates

from the alkalophilic bacterium Alcaligenes faecalis was 9.0 (Berla and Suseela, 2002). Lee, et. al., (2002) has reported that, the optimum $\mathrm{pH}$ of purified protease was $\mathrm{pH}$ 8. Nadeem et al., (2008) reported that $5 \mathrm{mM} \mathrm{Ca}^{2+}$ increased the stability of alkaline protease.

The results of stability studied showed that alkaline protease produced by Bacillus subtilis G-4 was stable over range of temperature and $\mathrm{pH}$ ( 8 to 11 ) in the presence of metal ions. The properties indicated that it can be used as a potential ingredient in detergent formulation.

\section{References}

Adinarayana K. and Ellaiah P. (2003). Production of alkaline protease by immobilized cells of alkalophilic Bacillus sp. J. Sci. Ind. Res., 62: 589-592.

Ali A. A. A. and Roushdy I. M. (1998). Fermentation of milk permeates by proteolytic bacteria for protease production. Appl. Biochem. Biotechnol, 74: 85-93.
Anwar A. and Saleemuddin M. ( 2001). Alkaline protease from Spilosoma oblique: potential applications in bioformulations. Biotechnol. Appl. Biochem, 31: 85-89.

Ammar M. S., Bayoumi R. A., El-Kasaby A. M. H and Soliman A. M. (2003). Purification and properties of thermostable protease by B. brevis geltinoamylolyticus using fish wastes (Fi.W.) and poultry wastes (Po.W) undersolid state fermentation (S.S.F.) conditions. 5th Int. Sic. Conf. Al-Azhar Univ.Fac. Sci. March 25-27, 2003 Cairo, Egypt. Pp.54.

Arai A., Kawachi E., Hata M., Ogura M. and Tanaka T. (2003). Inhibition of Bacillus subtilis aprE expression by lincomycin at the posttranscriptional level through inhibition of ppGpp synthesis. J. Biochem, 134: 691697.

Banerjee U. C., Sani R. K., Azmi W. and Sonny R. (1999). Thermostable alkaline protease from Bacillus brevis and its characterization as laundry detergent additive. Process Biochemistry, 35: 231-219. 
Balassa Sookkheo S., Sinchaikul S. and Chen. Phutrakul S. T. (2000). Purification and characterization of the highly thermostable protease from Bacillus stearothermophilus TLS 33. Protein Expr. Purif. 20: 142-151.

Beg K. B., Sahai V. and Gupta R. (2003). Statistical media optimization and alkaline protease production from Bacillus mojavensis in a bioreactor. Process Biochem, 39: 203-209.

Berla Thangam E. and Suseela Rajkumar G. (2002). Purification and characterization of alkaline protease from Alcaligenes faecalis Biotechnol. Appl. Biochem, 35: 149-154.

Dayanandan A., Kanagaraj J., Sounderraj L., Govindaraju R.and Rajkumar G. S. (2003). Application of an alkaline protease in leather processing: an ecofriendly approach. J. Cleaner Production, 11: 533-536.

El-Safey E . M. and Abdul-Raouf U. M. (2004). Production, purification and characterization of protease enzyme from Bacillus subtilis .International Conferences for Development and the Environment in the Arab World, Assiut Univ, March 23-25, p 14.

Feng Y. Y., Yang W. B., Ong S. L., Hu J. Y.and Ng W. J. (2001). Fermentation of starch for enhanced alkaline protease production by constructing an alkalophilic Bacillus pumilus strain, Appl. Microbiol. Biotechnol,. 57: 153-160.

Gupta R., Beg Q. and Lorenz P. (2002). Bacterial alkaline protease molecular approaches and industrial applications. Appl. Micribiol. Biotechnol, 59: 15-32.

He G .Q., Chen Q.H., Zhang L. and Liu X. J. (2003). Influence of medium components on elastase production using crude sources by Bacillus sp. EL31410, J. Zhejiang Univ. Sci. B, 4: 142-151.

Haki G. D. and Rakshit S. K. (2003). Developments in industrially important thermostable enzymes: a review. Biores. Techno, 89: 17-34.

Hornbeak T., Nielsen A. K., Dynsen J. and Jacobson M. (2004). The effect of inoculum age and solid verus liquid propagation on inoculum quality of industrial
Bacillus licheniformis strain. FEMS Microbiol Lett: 236: $145-151$

Jobin M. C. and Grenier D. (2003). Identification and characterization of four Proteases produced by Streptococcus Suis. FEMS Microbiol Let, 1: 113- 9.

Johnvesly B., Manjunath B. R. and Naik G. R. (2002). Pigeon pea waste as a novel, inexpensive, substrate for production of a thermostable alkaline protease from thermoalkalophilic Bacillus sp. JB-99. Bioresour Technol, 82: 61-64.

Joo H. S., Kumar C. G., Park C. G., Palk S. R. and Chang C. S. (2003). Oxidant and SDS stable alkaline protease from Bacillus clausii. 1-52: production and some properties. J.Appl Microbiol, 95: 267-72.

Kumar C. G. and Takagi H. (1999). Microbial alkaline proteases: from a bioindustrial viewpoint. Biotechnol.Adv, 17: 561-59.

Lee C. Y., Cheng M. F., Yu M. S. and Pan M. J. (2002). Purification and characterization of a putative virulence factor, serine protease, from Vibrio parahaemolyticus. FEMS Microbiol Lett, 19: 31-37.

Maurer K. H. (2004). Detergent proteases. Curr. Opin Biotechnol, 15: 330-334.

Mangat M. K. and Mandahr C. L. (1998). Effect of cultural conditions on the production of celluloses by Helminthosporium teres. Bull. Punjab Uni. Sci, 46: 139-145.

Mehrotra S., Pandey P. K., Gaur R. and Darmwal N. S. (1999). The production of alkaline protease by a Bacillus species isolate. Biores. Technol, 67: 201-203.

Nadeem M., Iqbal J. Q., Shahjahan B. and Qurat-ul-Ain S. (2008). Effect of medium composition on Commercially Important Alkaline Protease Production by Bacillus licheniformis N-2.Food Technol. Biotechnol. 46: 385-394.

Prakasham R. S., Rao C. S. and Sarma P. N. (2006). Green gram husk - An inexpensive substrate for alkaline protease production by Bacillus sp. in solid-state fermen- 
tation, Biosensors. Technol, 97: 1449-1454.

Rahman R. N. Z. R. A., Geok L. P., Basri M. and Salleh A. B. (2005). An organic solvent-tolerant protease from Pseudomonas aeruginosa strain K: Nutritional factors affecting protease production, Enzyme Microb. Technol, 36: 749-757.

Rao M. B., Tanksale A. P., Ghatge M. S. and Deshpande V. V. (1998). Molecular and biotechnological aspects of microbial proteases. Microbiol. Mol. Biol. R, 62: 579635.

Sandya C., Sumantha A. and Pandey A. ( 2004). Proteases enzymes, Enzyme Technol, 42: 312-325.

Shafee N., Aris S. N., Rahman R. N.R. A., Basri M. and Salleh A. B. (2005). Optimization of environmental and nutritional conditions for the production of alkaline protease by newly isolated bacterium Bacillus cereus strain 146, J. Appl. Sci. Res, 1: 1-8.
Ul-Haq I. and Mukhtar H. (2006). Fuzzy logic control of bioreactor for enhanced biosynthesis of alkaline protease by an alkalophilic strain of Bacillus subtilis. Curr Microbiol, 52: 149-52.

Werry N., Gerikev., Sharman A., Chaudhuri J. B., Hough D. W. and Danson M. J. (2003). Use of packed coulum bioreactor for isolation of diverse protease producing bacteria from Antarctic soil. Appl, Environ Microbiol, 69: 1457-64.

Yang S. S. and Huang I. (1994). Protease production by amylolytic fungi in solid state fermentation. $J$. Chinese Agric. Chem. Soc, 32: 589-601.

Received: October 12, 2010;

Accepted : June 21, 2011 